\title{
Mitochondrial haplogroup $C$ in ancient mitochondrial DNA from Ukraine extends the presence of East Eurasian genetic lineages in Neolithic Central and Eastern Europe
}

\author{
Alexey G Nikitin ${ }^{1}$, Jeremy R Newton ${ }^{2}$ and Inna D Potekhina ${ }^{3}$ \\ Recent studies of ancient mitochondrial DNA (mtDNA) lineages have revealed the presence of East Eurasian mtDNA \\ haplogroups in the Central European Neolithic. Here we report the finding of East Eurasian lineages in ancient mtDNA from two \\ Neolithic cemeteries of the North Pontic Region (NPR) in Ukraine. In our study, comprehensive haplotyping information was \\ obtained for 7 out of 18 specimens. Although the majority of identified mtDNA haplogroups belonged to the traditional West \\ Eurasian lineages of $\mathrm{H}$ and $\mathrm{U}$, three specimens were determined to belong to the lineages of mtDNA haplogroup $\mathrm{C}$. This find \\ extends the presence of East Eurasian lineages in Neolithic Europe from the Carpathian Mountains to the northern shores of \\ the Black Sea and provides the first genetic account of Neolithic mtDNA lineages from the NPR.
} Journal of Human Genetics (2012) 57, 610-612; doi:10.1038/jhg.2012.69; published online 7 June 2012

Keywords: archeogenetics; Dnieper-Donets Culture complex; mitochondrial DNA (mtDNA) haplogroups; Neolithic; North Pontic Region

\section{INTRODUCTION}

During the Neolithic, the North Pontic Region (NPR) was home to major prehistoric cultural conglomerates, among them-the DnieperDonets cultural complex (DD). The DD culture has been studied in approximately 200 sites in Ukraine and Byelorussia, including settlements and large collective cemeteries of the Mariupol-type (M-t). ${ }^{1}$ The main feature of M-t cemeteries is inhumation burial in the supine position. This burial rite differs from most local Mesolithic burial traditions and is characteristic of the 'Euro-Siberian' zone of extended burials, which are found from Lake Baikal and the forest and forest-steppe zones of the East European Plain to the northern part of Central Europe and Scandinavia. ${ }^{2,3}$

The distinct burial tradition of Neolithic populations of the NPR as well as their anthropological characteristics suggests an influx of external population sources. We set out to quantify the extent of gene flow into the NPR during the Neolithic. Recent advances in mitochondrial DNA (mtDNA) analysis have revealed global patterns of neutral marker variation that appear to correlate with the geographic origin of the source population., ${ }^{4,5}$ To elucidate the maternal genetic lineages of the population that constructed the M-t cemeteries, we undertook a genetic analysis of ancient mtDNA extracted from specimens from two Neolithic NPR cemeteries ${ }^{2}$ (Figure 1).

\begin{abstract}
MATERIALS AND METHODS
Origin of samples

Samples chosen for DNA analysis came from the anthropological collections of the Department of Bioarchaeology of the Institute of Archaeology in Kyiv, Ukraine. In most cases, only small cranial fragments were available for DNA extraction.
\end{abstract}

\section{Authenticity criteria}

There have been a variety of techniques suggested to minimize contamination with modern DNA, including amplifying small DNA fragments, cloning of PCR products and maintaining the strict conditions of sterility. ${ }^{6}$ These and other precautions were followed, such as minimizing the number of individuals handling the specimens and determining the mtDNA polymorphism pattern of the researchers who had the most direct contact with the specimens (Table 1). While such precaution controls the most likely source of modern DNA contamination, the possibility of contamination by other exogenous sources that came into contact with the specimens prior to DNA extraction may still persist.

Ancient mtDNA extraction, amplification and analysis All sample preparation, DNA extraction and initial amplification was performed by a single person (AGN) in facilities dedicated to DNA work with spatially separated cleanup, DNA extraction, amplification and post-PCR processing.

${ }^{1}$ Biology Department, Grand Valley State University, Allendale, MI, USA; ${ }^{2}$ Cell and Molecular Biology Department, Grand Valley State University, Allendale, MI, USA and ${ }^{3}$ Department of Bioarchaeology, Institute of Archaeology, National Academy of Sciences of Ukraine, Kyiv, Ukraine

Correspondence: Dr AG Nikitin, Biology Department, Grand Valley State University, 1 Campus Drive, Allendale, MI 49401, USA

E-mail: nikitin@gvsu.edu

Received 4 March 2012; revised 11 April 2012; accepted 14 May 2012; published online 7 June 2012 
Two temporary separated DNA extractions were performed per each osteological fragment. The surface of each specimen was treated with $253.7 \mathrm{~nm}$ ultraviolet for $45 \mathrm{~min}$ on all sides. Then, approximately $1 \mathrm{~mm}$ of the surface was sanded off, after which the ultraviolet treatment was repeated. Then, 300-400 mg of the bone were cut off per extraction and ground with mortar and pestle. The powder was washed with $0.5 \mathrm{M}$ EDTA pH 8.0 then rinsed with water. DNA was extracted using a QIAGEN QIAmp DNA

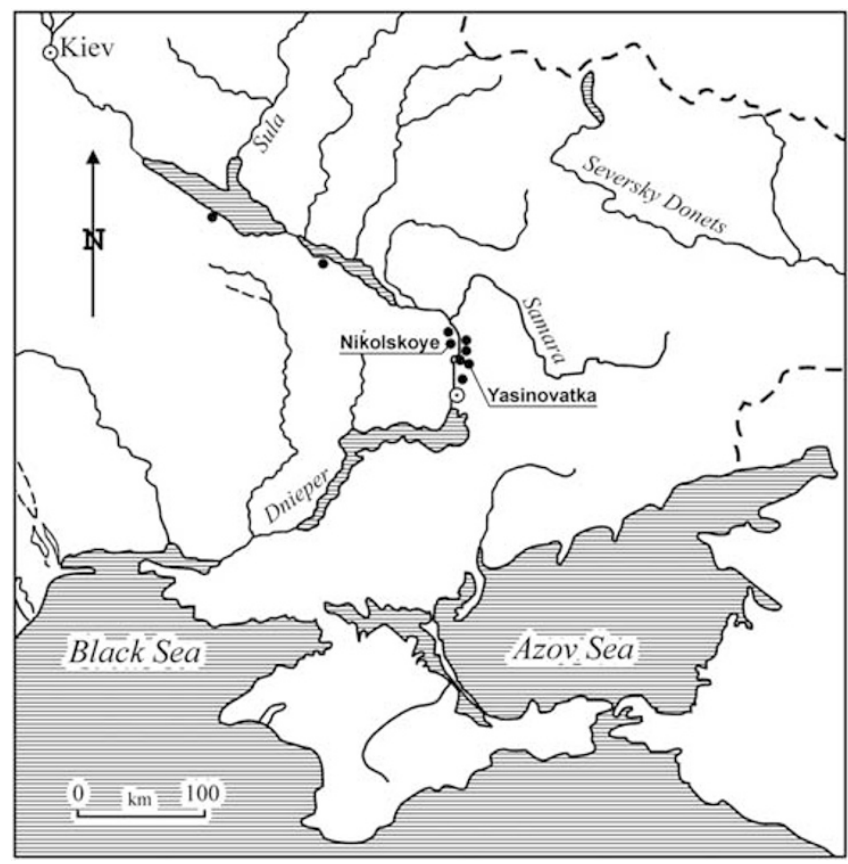

Figure $1 \mathrm{Map}$ of the North Pontic region showing locations of the Neolithic Mariupol-type cemeteries (Nikolskoye and Yasinovataka) from which specimens were selected for mtDNA analysis.
Investigator Kit (QIAGEN Inc., Valencia, CA, USA). Multiple blank extractions were performed for each specimen. DNA was eluted in $50 \mu$ of water.

DNA was typed by amplifying the first hypervariable segment (HVS1) of the control region of mtDNA in overlapping segments (Table 2). Amplifications of haplogroup-diagnostic segments of the coding region were subjected to restriction fragment length polymorphism (RFLP) analysis. Haplogroup designation based on coding region RFLPs was produced from at least three independent PCRs from two different extractions.

DNA amplification was done using a QIAGEN Fast Cycling PCR kit, following the conditions optimized for fragments in the 10 to 100 copy range. Each HVS1 segment was amplified up to 4 times per extraction or until two

Table 2 DNA primers used to amplify the control and diagnostic coding regions of mtDNA

\begin{tabular}{lll}
\hline Primer pair & Primer sequence $\left(5^{\prime}-3^{\prime}\right)$ & $\begin{array}{l}\text { Length of amplicon, bp } \\
\text { (region of coverage) }\end{array}$ \\
\hline L15993 & ACTCCACCATTAGCACCCAA & $142(15994-16092)$ \\
H16093 & GGTGGCTGGCAGTAATGTACGAA & $145(16086-16188)$ \\
L16085 & TGACTCACCCATCAACAACCGC & $161(16164-16277)$ \\
H16189 & CTTGCTTGTAAGCATGGGGA & \\
L16163 & ACTTGACCACCTGTAGTACATAA & $164(16266-16385)$ \\
H16278 & GTTAAGGGTGGTAGGTTGTTGG \\
L16265 & GCAACTCCAAAGCACCCCTCA & $123(6950-7051)^{\mathrm{a}}$ \\
H16386 & GATGGTGGTCAAGGACCCCTA & \\
L6949 & CCGTAGGTGGCCTGACTGGC & $123(12217-12308)^{\mathrm{b}}$ \\
H7052 & TGATGGCAAATACAGCTCCT & \\
L12216 & CACAAGAACTGCTAACTCATGC & \\
H12309 & ATTACTTTTATTTGGAGTTGCACCAAGATT &
\end{tabular}

Abbreviation: mtDNA, mitochondrial DNA; RFLP, restriction fragment length polymorphism. Primer sequence positions, coding region RFLP markers and polymorphic sites are given relative to the revised Cambridge Reference Sequence of mtDNA. ${ }^{26}$

aDiagnostic for haplogroup H (7028C-T; A/u/(-) RFLP). ${ }^{27}$

${ }^{b}$ Diagnostic for haplogroup U/K (12308G-A; Hinf/( + ) RFLP). ${ }^{27}$

Table 1 Specimen description, radiocarbon dates and mtDNA haplogroup designation for specimens from Mariupol-type cemeteries for which comprehensive haplogrouping information was obtained, along with mtDNA haplogroups of the researchers who handled and processed the osteological material

Specimen ID, burial type, morphological sex,

age, craniological type

mtDNA haplogroup

assignment

Radiocarbon dating, BP/cal $B C, 2 \delta$

Ni58, male 35-55, type $1 \mathrm{I}^{\mathrm{b}}$

Ni94, female, 50-60, n.a.

Ya19, female 20-25, type $I^{\mathrm{c}}$

Ya34, immature ( $<6$ years), n.a.

Ya36, male 30-50, type $1 \mathrm{I}^{\mathrm{b}}$

Ya45, male 20-25, type $\mathrm{Ic}^{\mathrm{c}}$

Ya64, male adultus, type $I^{\circ}$

Researcher 1 (archeology, anthropology)

Researcher 2 (DNA extraction, HVS1

PCR amplification)

Researcher 3 (cloning of PCR fragments, DNA sequencing, coding region PCR amplification,

RFLP analysis)

\begin{tabular}{|c|c|c|c|}
\hline $2305 \pm 45(0 x A 6156) / 508-206^{a}$ & Not $\mathrm{H}$ & $16223 \mathrm{C}-\mathrm{T}, 16298 \mathrm{~T}-\mathrm{C}, 16327 \mathrm{C}-\mathrm{T}$ & C \\
\hline $6225 \pm 75($ OxA 6155)/5358-4993 & $\mathrm{U} / \mathrm{K}$ & $16256 \mathrm{C}-\mathrm{T}, 16270 \mathrm{C}-\mathrm{T}, 16356 \mathrm{~T}-\mathrm{C}$ & U5ala \\
\hline $6370 \pm 60(0 \times A$ 6165)/5474-5225 & $\mathrm{U} / \mathrm{K}$ & $16343 \mathrm{~A}-\mathrm{G}$ & U3 \\
\hline $6195 \pm 80($ Ki 6786)/5323-4941 & Not $\mathrm{H}$ & $\begin{array}{l}16223 \mathrm{C}-\mathrm{T}, 16298 \mathrm{~T}-\mathrm{C}, 16327 \mathrm{C}-\mathrm{T}, \\
16357 \mathrm{~T}-\mathrm{C}\end{array}$ & $\mathrm{C} 4 \mathrm{a} 2$ \\
\hline $6260 \pm 180($ (OxA 5057)/5557-4792 & $\mathrm{H}$ & 16320C-T & $\mathrm{H}$ \\
\hline $6360 \pm 60(0 \times A$ 6164)/5471-5223 & Not $\mathrm{H}$ & 16223C-T, $16298 \mathrm{~T}-\mathrm{C}, 16327 \mathrm{C}-\mathrm{T}$ & C \\
\hline \multirow[t]{3}{*}{$6330 \pm 90 \mathrm{BP}(\mathrm{OxA}-5030) / 5479-5064$} & $\mathrm{H}$ & rCRS & $\mathrm{H}$ \\
\hline & & $16298 \mathrm{~T}-\mathrm{C}$ & V \\
\hline & & $16304 T-C$ & \\
\hline
\end{tabular}

16 163A-G, 16 186C-T, $16189 \mathrm{~T}-\mathrm{C}$,

T1

Abbreviations: mtDNA, mitochondrial DNA; n.a., not available; rCRS, revised Cambridge Reference Sequence; RFLP, restriction fragment length polymorphism.

HVS1 polymorphic sites are given relative to the rCRS of mtDNA. ${ }^{26}$

aThe date is likely erroneous considering that the northern part of the pit from which Ni58 came from is the oldest section of the Nikolskoye cemetery. ${ }^{3}$

bNonlocal ancient hypermorphic north-European population.

Indigenous Proto-European Mesolithic population. 
independent amplification products were obtained per extraction. The HVS1 amplicons were cloned and subsequently sequenced.

\section{RESULTS AND DISCUSSION}

Out of 18 samples analyzed, 14 produced mtDNA amplification. Comprehensive haplotyping information was obtained for seven specimens (Table 1). In seven specimens, the replicative analysis of ancient mtDNA could not be accomplished. DNA sequences have been deposited in GenBank (http://www.ncbi.nlm.nih.gov/genbank/) under accession numbers JN873355-873361.

Of the 286 HVS1 clones sequenced, only four (1.4\%) could be identified as belonging to one of the three principal researchers. Most clones displayed amplification-replica-specific random non-repeatable nucleotide misincorporations occurring at non-phylogenetically relevant positions, which is consistent with the expected post-mortem nucleotide damage. ${ }^{7,8}$

Two specimens were designated as members of haplogroup $\mathrm{H}$, two were members of the $U$ clade and three shared the 16223-1629816327 HVS1 sequence motif characteristic of the root sequence of haplogroup C. 9,10 Specimen Ya34 carried a transition at 16357, characteristic of the $\mathrm{C} 4 \mathrm{a} 2$ subbranch of the $\mathrm{C}$ clade. ${ }^{10}$

While the majority of mtDNA lineages found in the Neolithic remains from the NPR can be ascribed to the haplogroups of West Eurasian origin and are in agreement with those previously reported for prehistoric haplogroups in West Eurasia, ${ }^{11-18}$ our finding of East Eurasian lineages is uncommon in ancient European remains and has only been observed in the neighboring populations of the Carpathian Mountains. ${ }^{19,20}$

Haplogroup C is a derivative of the M8 subclade of the Asianspecific $\mathrm{M}$ clade. The frequency of $\mathrm{M}$-derived lineages in the modern mtDNA pool of Eastern Europe is marginal, with the exception of an isolated population of Carpathian highlanders. ${ }^{21}$ The haplogroup C HVS1 root sequence motif was frequent in ancient populations of the Tarim Basin. ${ }^{22}$ Modern Siberian populations as well as Neolithic populations of the Northern Baikal region and Northeastern Siberia have been found to harbor polymorphisms found in the C-bearing DD specimens. ${ }^{23-25}$ A C5-bearing specimen has been recently found in Neolithic Hungarian remains, ${ }^{20}$ extending the presence of the $\mathrm{C}$ clade in Neolithic Europe from the northern coast of the Black Sea to the Carpathians.

The overall conclusion about the genetic composition of the builders of $\mathrm{M}-\mathrm{t}$ cemeteries is that they were a genetically heterogeneous population that contained admixtures of mtDNA lineages from neighboring geographic regions as well as from the territories stretching far east. The noticeable anthropological influences of DD on local post-Neolithic populations suggest the possibility of genetic continuity in populations succeeding the people who built the M-t cemeteries. The genetic relationship between Neolithic DD populations and Copper-Bronze Age inhabitants of the North Pontic steppe is the subject of an ongoing investigation.

\section{ACKNOWLEDGEMENTS}

We thank Jessica Riley and Jeffrey Pashnick for careful reading and thoughtful comments on the manuscript. The study was supported in part by GVSU's Presidential Graduate Award to JRN.
1 Makarenko, M. O. The Mariupil Burial-Place (The Allukrainian Academy of Sciences, Kyiw, 1933).

2 Telegin, D. Ya. \& Potekhina, I. D. Neolithic cemeteries and populations in the Dnieper Basin - British Archaeological Reports International Series 383 (Archaeopress, Oxford, 1987).

3 Telegin, D. Ya. [Neoliticheskie mogil'niki mariupol'skogo tipa]. (Naukova dumka, Kiev, 1991).

4 Richards, M., Macaulay, V., Torroni, A. \& Bandelt, H.-J. In search of geographical patterns in European mitochondrial DNA. Am. J. Hum. Genet. 71, 1168-1174 (2002).

5 Torroni, A., Achilli, A., Macaulay, V., Richards, M. \& Bandelt, H.-J. Harvesting the fruit of the human mtDNA tree. Trends Genet. 22, 339-345 (2006)

6 Cooper, A. \& Poinar, H. Ancient DNA: do it right or not at all. Science 289, 1139 (2000).

7 Hansen, A. J., Willerslev, E., Wiuf, C., Mourier, T. \& Arctander, P. Statistical evidence for miscoding lesions in ancient DNA templates. Mol. Biol. Evol. 18, 262-265 (2001).

8 Gilbert, M. T. P., Willerslev, E., Hansen, A. J., Barnes, I., Rudbeck, L., Lynnerup, N. et al. Distribution patterns of postmortem damage in human mitochondrial DNA. Am. J. Hum. Genet. 72, 32-34 (2003).

9 Derenko, M. V., Grzybowski, T., Malyarchuk, B. A., Dambueva, I. K., Denisova, G. A. Czarny, J. et al. Diversity of mitochondrial DNA lineages in South Siberia. Ann. Hum. Genet. 67, 391-411 (2003).

10 van Oven, M. \& Kayser, M. Updated comprehensive phylogenetic tree of global human mitochondrial DNA variation. Hum. Mutat. 30, E386-E394 (2009).

11 Haak, W., Forster, P., Bramanti, B., Matsumura, S., Brandt, G., Tänzer, M. et al. Ancient DNA from the first European farmers in 7500-year-old Neolithic sites. Science 310, 1016-1018 (2005).

12 Haak, W., Balanovsky, O., Sanchez, J. J., Koshel, S., Zaporozhchenko, V., Adler, C. J. et al. Ancient DNA from European Early Neolithic farmers reveals their Near Eastern affinities. PLoS Biol. 8, e1000536 (2010).

13 Sampietro, M. L., Lao, O., Caramelli, D., Lari, M., Pou, R., Martí, M. et al. Palaeogenetic evidence supports a dual model of Neolithic spreading into Europe. $P$. Roy. Soc. Lond. B Bio. 274, 2161-2167 (2007).

14 Bramanti, B., Thomas, M. G., Haak, W., Unterlaender, M., Jores, P., Tambets, K. et al. Genetic discontinuity between local hunter-gatherers and Central Europe's first farmers. Science 326, 137-140 (2009).

15 Malmström, H., Gilbert, M. T., Thomas, M. G., Brandström, M., Storå, J., Molnar, P. et al. Ancient DNA reveals lack of continuity between Neolithic hunter-gatherers and contemporary Scandinavians. Curr. Biol. 19, 1758-1762 (2009).

16 Lacan, M., Keyser, C., Ricaut, F.-X., Brucato, N., Duranthon, F., Guilaine, J. et al. Ancient DNA reveals male diffusion through the Neolithic Mediterranean route. Proc. Natl Acad. Sci. USA 108, 9788-9791 (2011).

17 Lacan, M., Keyser, C., Ricaut, F.-X., Brucato, N., Tarrús, J., Bosch, A. et al. Ancient DNA suggests the leading role played by men in the Neolithic dissemination. Proc. Natl Acad. Sci. USA 108, 18255-18259 (2011).

18 Gamba, C., Fernández, E., Tirado, M., Deguilloux, M. F., Pemonge, M. H., Utrilla, P. et al. Ancient DNA from an Early Neolithic Iberian population supports a pioneer colonization by first farmers. Mol. Ecol. 21, 45-56 (2012).

19 Burger, J., Kirchner, M., Bramanti, B., Haak, W. \& Thomas, M. G. Absence of the lactase-persistence-associated allele in early Neolithic Europeans. Proc. Natl Acad. Sci. USA 104, 3736-3741 (2007).

20 Guba, Z., Hadadi, É., Major, Á., Furka, T., Juhász, E., Koós, J. et al. HVSpolymorphism screening of ancient human mitochondrial DNA provides evidence for N9a discontinuity and East Asian haplogroups in the Neolithic Hungary. J. Hum. Genet. 56, 784-796 (2011).

21 Nikitin, A. G., Kochkin, I. T., June, C. M., Willis, C. M., McBain, I. \& Videiko, M. Y. (2009) Mitochondrial DNA sequence variation in Boyko, Hutsul and Lemko populations of Carpathian highlands. Hum. Biol. 81, 43-58 (2009).

$22 \mathrm{Li}, \mathrm{C} ., \mathrm{Li}, \mathrm{H}$., Cui, Y., Xie, C., Cai, D., Li, W. et al. Evidence that a West-East admixed population lived in the Tarim Basin as early as the early Bronze Age. BMC Biol. 8, 15 (2010).

23 Mooder, K. P., Schurr, T. G., Bamforth, F. J., Bazaliiski, V. I. \& Savel'ev, N. A. Population affinities of Neolithic Siberians: a snapshot from prehistoric Lake Baikal. Am. J. Phys. Anthropol. 129, 349-361 (2006).

24 Ricaut, F. X., Fedoseeva, A., Keyser-Tracqui, C., Crubézy, E. \& Ludes, B. Ancient DNA analysis of human Neolithic remains found in Northeastern Siberia. Am. J. Phys. Anthropol. 126, 458-462 (2005).

25 Starikovskaya, E. B., Sukernik, R. I., Derbeneva, O. A., Volodko, N. V., Ruiz-Pesini, E. Torroni, A. et al. Mitochondrial DNA diversity in indigenous populations of the southern extent of Siberia, and the origins of Native American haplogroups. Ann. Hum. Genet. 69, 67-89 (2005).

26 Andrews, R. M., Kubacka, I., Chinnery, P. F., Lightowlers, R. N., Turnbull, D. M. \& Howell, N. Reanalysis and revision of the Cambridge reference sequence for human mitochondrial DNA. Nat. Genet. 23, 147 (1999).

27 Santos, C., Montiel, R., Anglés, N., Lima, M., Francalacci, P., Malgosa, A. et al. Determination of human Caucasian mitochondrial DNA haplogroups by means of a hierarchical approach. Hum. Biol. 76, 431-453 (2004). 